\title{
Usability and Digital Inclusion: Standards and Guidelines
}

\author{
Carlos Aleixo a , Miguel Nunes b \& Pedro Isaias a c \\ a Universidade Aberta (Portuguese Open University), Lisbon, Portugal \\ b University of Sheffield, Sheffield, UK \\ c ADVANCE Research Center-ISEG/UTL, Lisbon, Portugal
}

\begin{abstract}
This paper aims at discussing e-government website usability in relation to concerns about digital inclusion. Egovernment web design should consider all aspects of usability, including those that make it more accessible to all. Traditional concerns of social exclusion are being superseded by fears that lack of digital competence and information literacy may result in dangerous digital exclusion. Usability is considered as a way to address this exclusion and should therefore incorporate inclusion and accessibility guidelines. This paper makes an explicit link between usability guidelines and digital inclusion and reports on a survey of local government web presence in Portugal.
\end{abstract}

Keywords: usability guidelines, digital inclusion, local e-government, information literacy

\section{Introduction}

In the information society that has characterised the last two decades, knowledge, information and communication in digital form have become the crucial factor in economic growth, economic competition and social development. Not surprisingly, e-government has emerged as a vehicle to better and faster dissemination of government information, interaction with government and citizen participation. It was expected since its inception that e-government would create new economic and social opportunities for individuals, by promoting access to and dissemination of information ( $\mathrm{Li}, 2005$; Traunmuller \& Wimmer, 2001). However, many countries and millions of people continue to have difficulties with both the concept and its implementation. Citizens and governments seem to "drift in this new reality" (Kummer, 2003). Developments in e-government meet with user resistance (Evans \& Yen, 2006) and fears of job losses among public servants (Heeks \& Bailur, 2007) as well as the failure and over-running of implementations (Heeks, 2005). This raises both problems of trust in egovernment and risks in its implementation by governments (Bélanger \& Carter, 2008). Therefore, and despite all the academic hype and political rhetoric, the focus on what the technology can do has led to consistent problems. Irani et al. (2007) suggest that the key issues that need to be tackled are about the suitability of technology in government processes rather than developing the right technology.

In fact the focus on technology is driving the information age forward but, paradoxically, is causing the emergence of new divisions and exclusions (Bindé, 2005). Digital division (DiMaggio et al., 2001) and digital exclusion (eInclusion@EU, 2004) are new problems that need to be alleviated through careful and purposeful design and of e-government. This must include design of access, adaptation of content and creation of new modes of interaction 
between citizens and government. According to Warschauer (2003) this should encompass the following aspects:

i. physical: involving access to computers and telecommunications

ii. digital: consisting of material (content and applications) that is available online

iii. social: involving community structures and social institutions

iv. human: considering education and literacy.

This research focuses on the human aspects of information literacy as a crucial factor that influences the ability to use information and communication technologies in general and egovernment in particular (Dutton, 2004; Warschauer, 2002, 2003). Information literacies are built upon the traditional forms of literacy (reading, writing and arithmetic) and encompass both new forms of information and knowledge representation and Internet-specific competences and skills.

This paper argues that there is a need for specific usability guidelines to help designers of egovernment mitigate the effects of these digital exclusion phenomena. The use of such usability guidelines is presented here as a means to reduce the difficulties of public use of sites on the World Wide Web (from now on referred to in this paper as the Web) caused by low levels of literacy. The paper presents the findings of a research project that aimed at explicitly relating usability to digital inclusion in the design of local government websites in Portugal. A study of this nature is particularly important for Portugal due to its inherent demographic characteristics. Having emerged from a very conservative right wing dictatorship in 1974, Portugal joined the EU in 1986 with an inheritance of low literacy that is still significant today. A close inspection of the table shown in Annex 1, shows that in 2004 only $49 \%$ of the population has completed Secondary Education, 11\% Higher Education and $0.45 \%$ a $\mathrm{PhD}$. Therefore, issues of digital inclusion are fundamental to assess the success of egovernment initiatives in a country exhibiting this type of demographic statistics.

\section{Digital Inclusion}

The digital divide has traditionally been used to describe discrepancies between socioeconomic, ethnic or minority groups and their corresponding access to, use of and exploitation of information and communication technologies (ICT), as well as access to the social and organisational resources needed to use and exploit these technologies (Norris, 2001a, 2001b; Warschauer, 2004; Waycott et al., 2010). Consequently, digital inclusion refers to the effective participation of individuals and communities in all dimensions of the knowledge-based society and economy through their access to ICT, made possible by the removal of access and accessibility barriers, and effectively enabled by the willingness and ability to reap social benefits from such access (eEurope Advisory Group, 2005).

The apparent inequalities (1) in the access to and use of ICT and, consequently, (2) in the exploitation of its benefits for personal and social development, are not the result of a phenomenon that represents a simple duality between "haves and have-nots" in terms of access to ICT (Dutton, 2004; Hargittai, 2002; Lynch, 2002; Warschauer, 2002). In fact, it has been widely suggested that the traditional socio-economic differences that have dictated access to technology are not the fundamental factor in digital inclusion. Authors such as Prensky (2001), Madden et al. (2007) and Underwood (2007) have proposed that the digital divide is a complex of interacting physical, digital, human, and social resources that is based instead on generationally related differences in technology use and skills (e.g. "digital 
natives" vs "digital immigrants"). These differences emerge from different education and professional backgrounds that influenced the life and personal experiences of digital natives, namely use of ICT in education and work, understanding of potential and usefulness of Internet technologies and capacity to properly use the Internet as both an information and communication resource.

Therefore, even in so-called "high tech" countries, there is a failure of some individuals and communities to make ideal use of ICT in compliance with new social practices, such as egovernment. Therefore, these groups are under-represented in the new world of e-government and have difficulties in defending their social, economic and political interests. Mitigating the digital divide and supporting social inclusion in e-government imply a national, regional and local assurance of a set of factors and resources, as proposed by several authors such as Warschauer (2002), namely:

- easily accessible computer and networked infrastructures

- relevant, multilayered, multilingual, flexible and easily usable content and services

- appropriate levels of literacy and education that enable the use of the digital content and services provided

- community and institutional support.

Failure to address these factors will contribute to the deepening of digital divisions (DiMaggio, et al., 2001). The combined absence of any of these four factors results in a complex and wide range of digital exclusion dimensions (Bagchi, 2005; Castells, 2001; eEurope Advisory Group, 2005; Guillén \& Suárez, 2005; Huang et al., 2003; OECD, 2001; Warschauer, 2003).

This study focuses on understanding the relationship between the design of content services for the lowest common denominator of digital literacies in a particular social environment.

\section{Digital Inclusion, Information Literacy and E-government}

The work of Bawden (2001) on information literacy and digital literacy shows that the meaning of the term 'literacy' has had a variety of meanings with significant changes over time. For the purpose of an e-government study, it surely is more important to focus on what a participative and literate citizen is expected to do while using e-government content and services. Curiously, this expectation of literacy has been widely discussed since the proposition of the information literacy concept by Paul Zurkowski in the 70s and was well defined by Doyle (1992). Information literate citizens are those who:

- recognise their needs for information

- recognise that accurate and complete information is the basis for intelligent decisionmaking

- identify potential sources of information to resolve their information needs

- develop their own successful search strategies

- are able to access sources of information both on- and off-line

- evaluate information retrieved and selected

- organise that information for practical application

- integrate new information into their existing body of knowledge

- use information in critical thinking and problem solving. 
One important implication emerging from this characterisation is that the e-citizen is supposed to be literate in all media, including electronic media on the Internet. An additional implication of this set of competences, as pointed out by the UK Educational Testing Service (2002) and Shetzer and Warschauer (2000), is the need to define a set of higher-level macrocompetences and skills that actually represent the instantiation of the set in today's information and knowledge society. These could be subdivided into two main categories: cognitive competences and ICT competences. Cognitive competences comprise the fundamental skills in day-to-day life and, in terms of literacy, include reading, writing, numeracy, problem solving and critical thinking, spatial literacy and visual literacy. ICT competences refer to the integration and application of cognitive skills and techniques to enable people to maximize the capabilities of these technologies. These can be summarized in terms of the technique necessary to use the ICT itself, in the search for information, in communication, and in the construction of contents (Shetzer \& Warschauer, 2000). These competences were specifically used in Annex 3 in order to qualify the evaluation of the usability guidelines.

The integration of the technology and cognitive macro-level competences lead to a redefinition of digital literacy as a set of competences and skills which a person needs in order to use digital technologies, communication media, social networking tools and networked information and thus become able to be actively involved in a society based on information and knowledge. These competence-based digital literacies comprise (Shetzer \& Warschauer, 2000; Warschauer, 2003):

- Computer literacy: The term 'computer literacy' emerged at the beginning of the eighties of the twentieth century, along with the emergence of personal computing (Hoffman \& Blake, 2003). According to Williams (2003), computer literacy has acquired a skills connotation, implying competence in using and exploiting today's computer applications, such as word processing and email, as well as the ability to physically operate and manipulate computer technology. However, it is important to note that feeling comfortable and knowledgeable about current hardware, software, networks and operating systems should not be an end in itself. These skills are important components of a broader learning and cognitive process. This may be an apparent truism today, in face of the exponential growth and evolution of technologies; however, more than a decade ago, the US National Research Council Committee on Information Technology Literacy (1999; cited by Williams, (2003) was already warning that:

[Computer] Literacy is too modest a goal in the presence of rapid change, because it lacks the necessary staying power. As the technology changes by leaps and bounds, existing skills become antiquated and there is no migration path to new skills. [...] To adapt to changes in the technology [...] involves learning sufficient foundational material to enable one to acquire new skills independently after one's formal education is complete. (NRC 1999 p 2)

Therefore, literate e-citizens need to acquire an additional set of competences that in association with computer literacy enable them to engage in long-term sustainable activity in the online world. Computer literacy by itself is insufficient. 
- Information literacy: Information literacy encompasses the analytical and critical skills required to understand information needs, formulate research questions, search for and access a variety of information types, evaluate the results of these searches in order to meet identified information needs and, finally, be able to process and apply this information in practice (Lenox \& Walker, 1993; Webber \& Johnston, 2000). Therefore, information literacy involves the use of computer literacy in terms of specific knowledge of technology (e.g. using a browser and search engines) but requires a new set of cognitive competences (e.g. analysing and evaluating sources of information). Processing the large amounts of information available via the Web, as well as dealing with information overload and information anxiety is therefore only within reach of those who have appropriate information literacy skills and competences. Therefore, promoting information literacy should be an important objective for social inclusion and a necessary requirement for the implementation of e-government.

- Multimedia literacy: In very simple terms, multimedia literacy is the use of computerbased technology to present and combine text, graphics, audio, and video with links and tools that let the user navigate, interact, create, and communicate (Hofstetter, 2003). Therefore, multimedia literacy is concerned with the creation of meaning in the everchanging world of computer-based technology and the Web: that is, the ability to interpret and produce documents combining texts, sounds, graphics, and video (Warschauer, 2007). According to J. Lemke (2000) multimedia literacy comprises simultaneously three kinds of meaning: presentational, orientational, and organisational. Presentational meanings are those that tell something about the world, about a state of affairs or relationship, and which construe in words the doings and beings we wish to present (J. Lemke, 2000). Orientational meanings refer to the literacy skills necessary to identify and process the intended stance of the multimedia content in terms of its prospective users, their attitude and viewpoint towards other similar contents and its own presentational design (J. L. Lemke, 1998). That is, the user should be able to analyse what has been constructed, its ideal prospective user, as well as the expectations, attitudes and intentions likely to have been behind the creation of the multimedia content. Organisational meaning is the creation of meaning by which the designers "show what goes with what, what are the units, the wholes and parts, the internal connecting relations of [... multimedia contents] that makes it distinct from a collection of isolated and unrelated [fragments of the web]" (J. Lemke, 2000).

- Computer-mediated communication literacy: This refers to the mastery of the pragmatics of synchronous and asynchronous computer-mediated communication (CMC) (Warschauer, 2007): that is, the ability to express oneself, interpret and interact online in order to communicate effectively. CMC literacy ranges from the ability to use "netiquette", which corresponds to the informal rules and conventions of common courtesy online, to the capability of argumentation and persuasion. From the point of view of technological competence, CMC literacy may even include knowing how to establish and manage online communications for the benefit of groups of people (e.g. discussions and training online).

In sum, digital literacies can be seen as a combination of technological and cognitive competences and expressed in terms of a set of computer, information, multimedia, and CMC literacies. Lack of these literacies may result in digital exclusion. Consequently, successful egovernment depends on active and participative digitally literate citizens. 
E-government refers to the use by government agencies of information technologies (such as Wide Area Networks, the Internet, and mobile computing) that have the ability to transform relations with citizens, businesses, and other arms of government. These technologies can serve a variety of different ends: better delivery of government services to citizens, improved interactions with business and industry, citizen empowerment through access to information, or more efficient government management. The resulting benefits can be reduced corruption, increased transparency, greater convenience, revenue growth, and/or cost reductions (World Bank, 2005).

If aspects of the digital divide are not seriously considered, the adoption of this innovative form of government is limited to those who have access to technology and the literacies and competences to exploit these electronic services. In this sense, as highlighted by Carter and Bélanger (2004), e-government in itself can be a major contributor to the deepening of the digital divide in society. To mitigate this situation, the development and design of egovernment sites and services should include a set of usability guidelines and recommendations that are closely related to the digital literacies identified above. Usability, which is related to how easy it is to use a technological artifact (Jackob Nielsen \& Loranger, 2006 , p. xvi), is therefore a requirement for successful delivery of services provided by egovernment to citizens (Millard, 2004).

\section{Research Question and Methodological Approach}

The study reported in this paper aimed at exploring the relationship between usability and digital literacies with the ultimate goal of proposing ways to bridge the digital divide. The study also aimed at surveying the e-government reality in Portugal.

E-government strategy in Portugal has been developed according to a more general Information Society policy established in September 2009. This policy known as the Technology Plan (http://www.planotecnologico.pt/en/technological-plan/about-theplan/list.aspx) consists of a "series of articulated transversal measures aimed among other things at stimulating innovation by Portuguese companies, fostering research \& development activities, improving education and training, and modernising the Public Administration" (European Commission, 2009). According to the Cabinet of the National Coordinator for the Lisbon Strategy and Zorrinho (2006) the Technology Plan was developed according to the following three main axes:

- Knowledge - To qualify the Portuguese for the knowledge society, fostering structural measures which aim at enhancing the average qualification level of the population, implementing a broad and diversified lifelong learning system and mobilising the Portuguese for the Information Society.

- Technology - To overcome the scientific and technological gap, reinforcing public and private scientific and technological competences and recognising the role played by enterprises in the process of creation of qualified jobs and Research \& Development (R\&D) related activities.

- Innovation - To boost Innovation, helping the productive chain to be adapted to the challenges of Globalisation by means of diffusion and development of new procedures, organizational systems, services and goods.

The specific interest for the development of e-government in Portugal is one particular section of the Technology Plan, entitled Connecting Portugal (http://www.english.umic.pt/images/ 
stories/publicacoes2/conn_pt.pdf). This sub-policy is particularly devised to resolve issues of inclusion in Portugal and established the following key objectives as stated by Portuguese Ministry of Science, Technology and Higher Education (2005):

- To promote a modern citizenship;

- To guarantee a competitive national market of telecommunications;

- To ensure the transparency of the Public Administration;

- To promote the increasing use of Information and Communication Technologies;

- To foster technological and scientific development.

Despite this careful strategic planning sustained effort in the development of e-government, Europe and the country itself were surprised when Portugal was reported to be the leader in the European Union in public online service sophistication and availability by the eGov 2010 benchmark report published by the European Commission on 21 February (Capgemini et al., 2010). Portugal ranked top in the European tables not only for the sophistication and availability of public online services, but also in usability, user-centric design, and service bundling (Capgemini, et al., 2010, p. 9).

Nonetheless, and from the point of view that drove this research, the question that still remained to be answer was: can this apparent success promote modern citizenship as initially advocated by the Technology Plan? This promotion of modern citizenship should result according to the definition of the Portuguese Ministry of Science, Technology and Higher Education (2005) in a new type of citizenship that is "informed, conscious and active, for which the use of Communication and Information Technologies is a natural tool for the access to information, education, cooperative work and public debate".

Therefore, this research was interested in investigating whether this image of success also addressed the issues of the digital inclusion and digital literacy - necessary for this new concept of citizenship - in both usability and design. That is, this research was interested to relate this clear success in design with the need to go beyond graphic design, navigability, functionality and accessibility. Thus, the research question driving this study was expressed as:

"Does the very successful usability of Portuguese Municipalities' websites reflect concerns with digital inclusion?"

In order to respond to this question, and since there is very little literature available which explicitly connects the usability and digital literacies concepts, the research project started by trying to establish a detailed set of usability guidelines that were clearly linked to digital literacies. This was followed by a desktop cognitive walkthrough (CW) study that investigated 28 local government websites in Portugal.

The CW is traditionally used as an usability evaluation method, with special attention to how well the interface supports 'exploratory learning', i.e. first-time use without formal training (Rieman et al., 1995). It focuses on evaluating user interfaces of a system as to assess ease of learning, particularly by exploration, i.e. guessing what to do using the signals provided by the system. Based on early propositions by Wharton et al. (1994), CW simulates users performing navigation tasks on a website by assuming that users perform goal-driven exploration (Blackmon et al., 2002). 
CW is based on Lewis and Polson's CE+ theory of exploratory learning (Polson et al., 1992) and usually involves the following set of general steps (Lewis \& Rieman; Rieman, et al., 1995):

1. A list of the tasks that are expected to be performed by the user is established.

2. These tasks should be decomposed into two parts:

a. the user's expected intentions and goals

b. what users must achieve in order to attain the goals.

3. The investigator "wears the users' shoes" (Tonkin, 2005) by trying out each step on the system or prototype version of the interface under evaluation.

4. The investigator fills in the Walkthrough Evaluation Sheet (WES) for each step taken, criticised and evaluated.

This method is particularly useful for the study reported since it focuses on simulating the process of resolving users' behaviour problems for ease of learning (Wharton, et al., 1994) and assuming that no specific formal training was provided to the same user. This is particularly applicable to e-government usability evaluation and the testing of required digital literacy.

\section{Matching Existing Usability Guidelines with Digital Inclusion}

Before proceeding with the $\mathrm{CW}$ planned for the study, there was a preliminary step that had to be completed, namely linking existing usability guidelines and digital literacy. However, this proved to be a much more demanding task than initially expected. There are a number of different and not always compatible sets of guidelines, proposed by different authors with different aims. These guidelines are often in conflict with each other, so that the choice of one prevents the implementation of another. To complicate the scenario in usability studies, the more general a rule is, the greater the possibility of conflict with other rules and the greater the need to understand the theory that supports it (Dix et al., 2004, p. 259).

In fact, the present researchers found considerable problems in defining a base set of usability guidelines for this research, due to:

- the large number and different types of guidelines (Jakob Nielsen, 1993, p. 93); e.g. the compilation of about 1000 guidelines for the design of user interfaces (Smith \& Mosier, 1986)

- a tendency for these guidelines to have little authority and in some cases little evidence of application supporting them (Dix, et al., 2004, p. 259)

- the gaps in some of these existing guidelines, which at times are incomplete or not supported by research work (Rohn et al., 2002)

- the fact that many of them are contradictory to each other and sometimes even contradict the empirical research (Rohn, et al., 2002).

Given the need to select a base set of usability guidelines and then adjust these to reflect digital divide concerns, the research team followed the process of selection proposed by Brajnik (2004) and decided to adopt the Research-Based Web Design \& Usability Guidelines used by the US Health and Human Services Department (2006). 
In order to adjust the selected usability guidelines to reflect digital inclusion concerns, the team had to reduce further the level of abstraction of the macro-competences discussed above and define detailed and precise micro-competences. The model of micro-competences established - SCONUL+1 - is presented in Figure 1 (for a complete view, please see Annex 3) and was based on:

- macro-competences from the literacy of digital literacy, as defined in this study

- the model of the seven pillars of information literacy from SCONUL'(Bainton, 2001)

- the term 'learning outcome' (Wareing, 2004)

- the case studies for the development of information literacy of students produced by SCONUL (2004).

The work of adjusting the Research-Based Web Design \& Usability Guidelines using SCONUL+1 was done according to the procedure of verifying the applicability of each guideline to support each micro-competence, answering the question: does the usability guideline support any of the micro-competences in SCONUL+1?

The verification observed whenever possible the heuristic proposed by Souza \& Bevan (1990), by addressing:

- the benefits and design goals within the context of e-government

- the conditions on which the guideline supports SCONUL+1

- the nature of e-government and the digital divide

- any procedure for the implementation of the guideline in e-government.

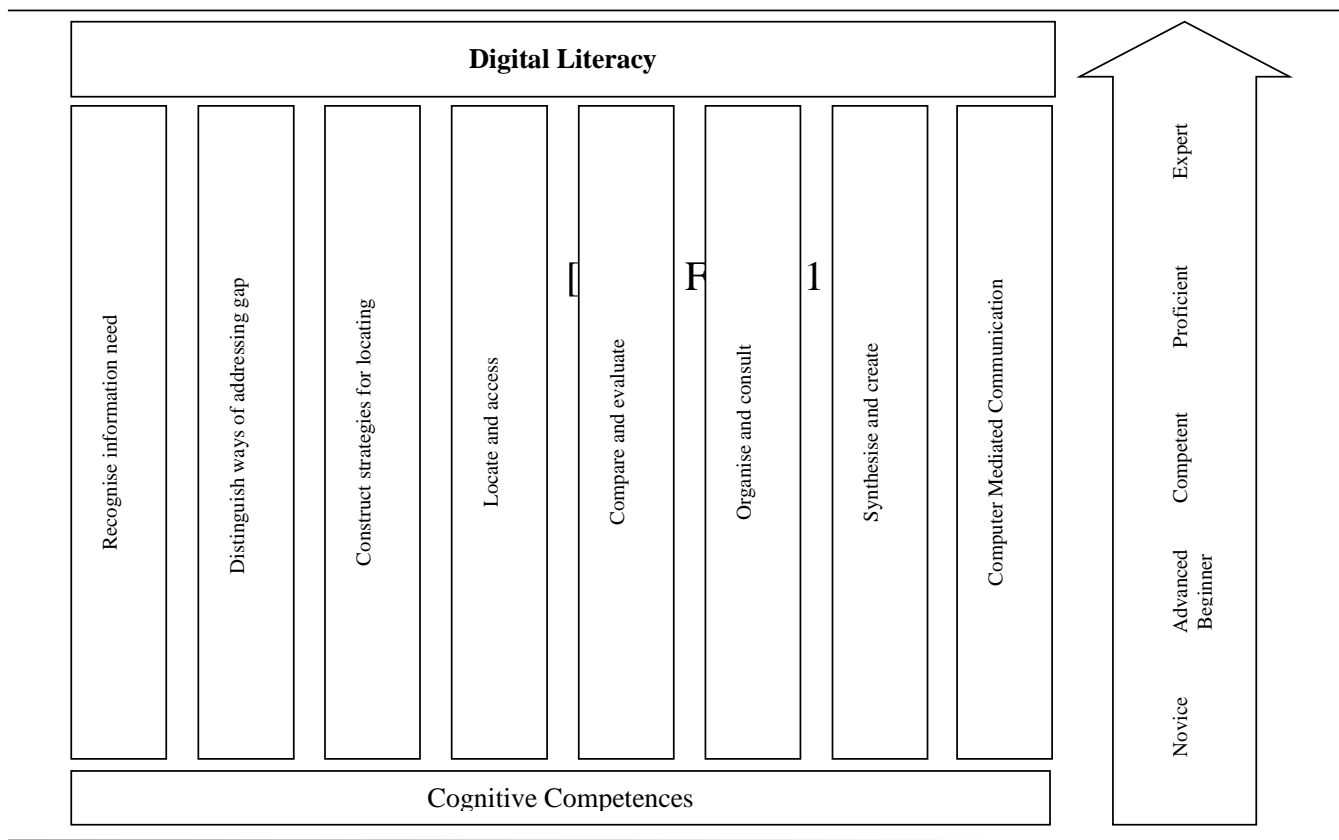

Figure 1. SCONUL ${ }^{+}$- Digital literacy model, based on the information skills model (SCONUL, 2004), on the framework for ICT literacy (Educational Testing Service, 2002), and on the works of Shetzer and Warschauer (2000) and Warschauer (2003).

1 SCONUL - Society of College, National and University Libraries: involved in developing the profile of information literacy in higher education since 1997 (www.sconul.ac.uk/groups/information literacy). 
This adjustment process and subsequent guideline selection resulted in a subset of 53 usability guidelines for digital inclusion which are presented in Annex 2. 52 came directly from the Research-Based Web Design \& Usability Guidelines. One was added (with the code 2:a in Annex 2) because, when usability guidelines were assessed in terms of feedback provided to users, the existing guideline 2:10 - Provide feedback when users must wait - was deemed not to contain the necessary breadth. To enable $\mathrm{CW}$, an extra table was constructed detailing the connection between the micro-competences and the subset of usability guidelines selected (please see Annex 3).

\section{Research Design and Process}

Performing the CW using the table in Annex 3 meant evaluating 28 local government websites in Portugal, selected to represent a significant sample of the Portuguese national scene. The execution of tasks of the cognitive walkthrough was recorded in video format, and the data collected provided a numerical interpretation of a five-point Likert scale for each task ('very poor'; 'poor'; 'reasonable'; 'good'; 'very good'). Both the score and all qualifying comments were stored in a purpose-built tool - MunAva. This system was designed and developed using an architecture based on Microsoft.NET and SQL Server Express and is illustrated in Figure 2. All collected data were analysed at the end of the walkthrough process.

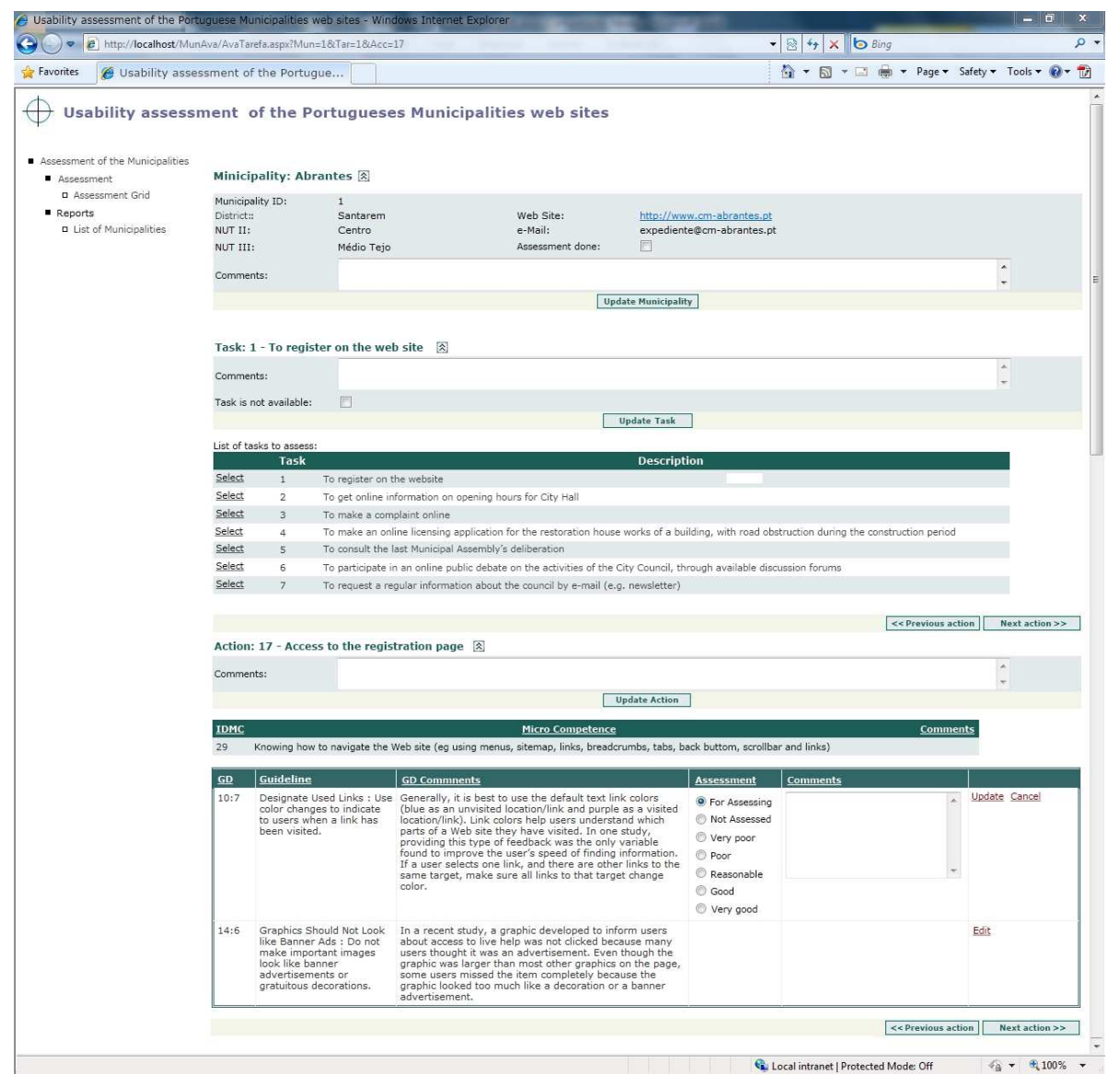

Figure 2. MunAva Evaluation Collection Tool 
In detail, the following CW phases, as proposed by Wharton et al. (1992), were undertaken:

1. Preparatory phase: defining the user profile, the tasks that test digital literacies and the actions to be taken:

- Users: Portuguese citizens with low levels of digital literacy skills, seeking information or using services on the websites of Portuguese municipalities.

- Tasks: the number of tasks had to be limited but representative. Since the CW does not provide guidance for the selection of tasks to be used in evaluation, the guidelines of Wharton et al. (1992) were followed and the following tasks defined and designed:

$\circ$ to register on the website

$\circ$ to get online information on opening hours for City Hall

○ to make a complaint online

○ to make an online licensing application for restoration work on a building, with road obstruction during the construction period

- to consult the most recent deliberations of the Municipal Assembly's

- To participate in an online public debate on the activities of the City Council, through available discussion forums

- To request regular information about the council by e-mail (e.g. newsletter).

- Actions: each of the above high-level tasks may require the e-government user to take several actions. Therefore, for each task a detailed list of actions was devised and directly related to the defined micro-competences necessary for their execution (see Table 1 for a detailed example).

\begin{tabular}{llll} 
Task & \multicolumn{2}{l}{ Action } & Micro-competence \\
\hline To register on the website & 1 & Find access to the registration page & $\begin{array}{l}3 ; 9 ; 10 ; 12 ; 13 ; 14 ; 16 ; 29 ; 30 ; \\
31 ; 32 ; 39\end{array}$ \\
\cline { 2 - 4 } & & & 29 \\
\hline 2 & Access to the registration page & $5 ; 36 ; 37 ; 38 ; 39 ; 40$ \\
\hline 3 & Read and interpret & $39 ; 41 ; 42 ; 45 ; 48 ; 50 ; 57 ; 58 ;$ \\
\hline 4 & Fill out the registration form & $59 ; 60$ \\
\hline & & $42 ; 49 ; 50$ \\
\hline 5 & Register & Be sure that the registration was done & 49 \\
\hline
\end{tabular}

Table 1. Example of the definition of a task and respective actions and micro-competences.

2. Analysis phase: The analysis phase was performed by attempting to execute the tasks identified in the preparatory phase. The execution of these tasks always started from the homepage of the municipality website being evaluated. It consisted in verifying the compliance of the interfaces of the municipality's website with the usability guidelines identified for digital inclusion and the objective of minimizing the need for a certain competence. The result of the analysis was expressed, as indicated above, in terms of a five-point Likert scale ('very poor'; 'poor'; 'reasonable'; 'good'; 'very good'). 
Additionally, options were added for the following exception where constraints could arise during the evaluation:

- A Boolean option was added to reflect if the task or any of the actions was achievable or not on the website under evaluation.

- Since the combination of usability guidelines to micro-competences was designed independently of the tasks used in the evaluation, the option 'not rated' was added to the guideline level and used in the following two cases:

(1) Guidelines unverified by the way the task or action was done

(2) Guidelines not applicable in the assessment task or action.

The unit of evaluation comprised the identification of the municipality, the tasks, the actions performed to accomplish each of the tasks and the usability guidelines for each action.

\section{Interpretation of results phase:}

The data collected for each municipality were first analysed and interpreted on an individual level and then compounded to obtain a holistic view. Since the data were collected using a Likert scale, only discrete statistics were used, namely through the use of medians and frequencies. The summarized results are presented in the next section in both tables and charts.

\section{Research Findings}

As discussed above, the CW process was based on trying to perform seven basic tasks on municipal websites. Table 2 provides an overview of the tasks performed and the municipal websites that allowed the task to be performed. From a quick analysis of this table it is immediately apparent that tasks 4, 5 and 6 are not supported by the great majority of sites. These tasks aimed at testing different aspects of e-government provision and it emerged that only one of the sites provided a discussion forum and that one other provided direct access to the Municipal Assembly's deliberations. This shows a low level of transparency and encouragement of citizen participation, but did not enable the researchers to draw conclusions in terms of usability for digital inclusion.

More interestingly, the majority of municipalities supported tasks 1, 2, 3 and 7 . Therefore, the execution of these tasks, and the subsequent evaluation, proved much richer in terms of assessing site usability and corresponding attention given to digital literacies requirements. 
Total municipalities

with the task available

Task 1

To register on the website 16

Task 2

Get online information on opening hours for

City Hall

Task 3

Make a complaint online

13

Task 4

Make an online application for a licence for restoration works on a building with the road occupation during the construction period

Task 5

Consult online the last Municipal Assembly's deliberation

1

Task 6

Participate in online public debate on the activities of the City Council through discussion groups 1

Task 7

Request regular information about the council by e-mail (e.g. newsletter) 16

Table 2. Tasks performed per Municipality website

Table 3 depicts the overall evaluation of the task performance, taking concerns over digital inclusion into consideration. One important conclusion is that none of the websites supported all the tasks. Again, that does not help in understanding compliance with usability guidelines in the design of the websites evaluated. From the evaluation of those tasks that were actually performed successfully, as depicted in Table 3, three main conclusions emerge:

- With very few exceptions, the overall scenario is reasonable, but not entirely satisfactory. Most evaluations scored values around 3 ('reasonable') and 2 ('poor') when digital inclusion concerns were taken into account. This scenario was confirmed by compound results both per municipality and per task.

- Task 7 revealed severe lacks in design for digital inclusion. In general terms, the design of the websites in relation to supporting citizens in subscribing to either email information lists or municipal online newsletters was extremely poor. Many of the sites assumed levels of literacy and understanding of semiotic symbology that were far beyond the average citizen's capabilities. Some even required the understanding of third party technology that also required a steep learning curve and extra training by the user. There was an additional problem related to the provision of feedback after the subscription attempt, which left the user anxious and unsure of the success of the task.

- Only two municipalities got a compound score of 4 ('good'), and none scored 5 ('very good'). This reveals on one hand a fairly homogenous scenario, but on the 
other a fairly poor one. In fact, in terms of usability guidelines that are explicitly linked with digital literacies, the situation is far from being as positive as the aforementioned (Capgemini, et al., 2010).

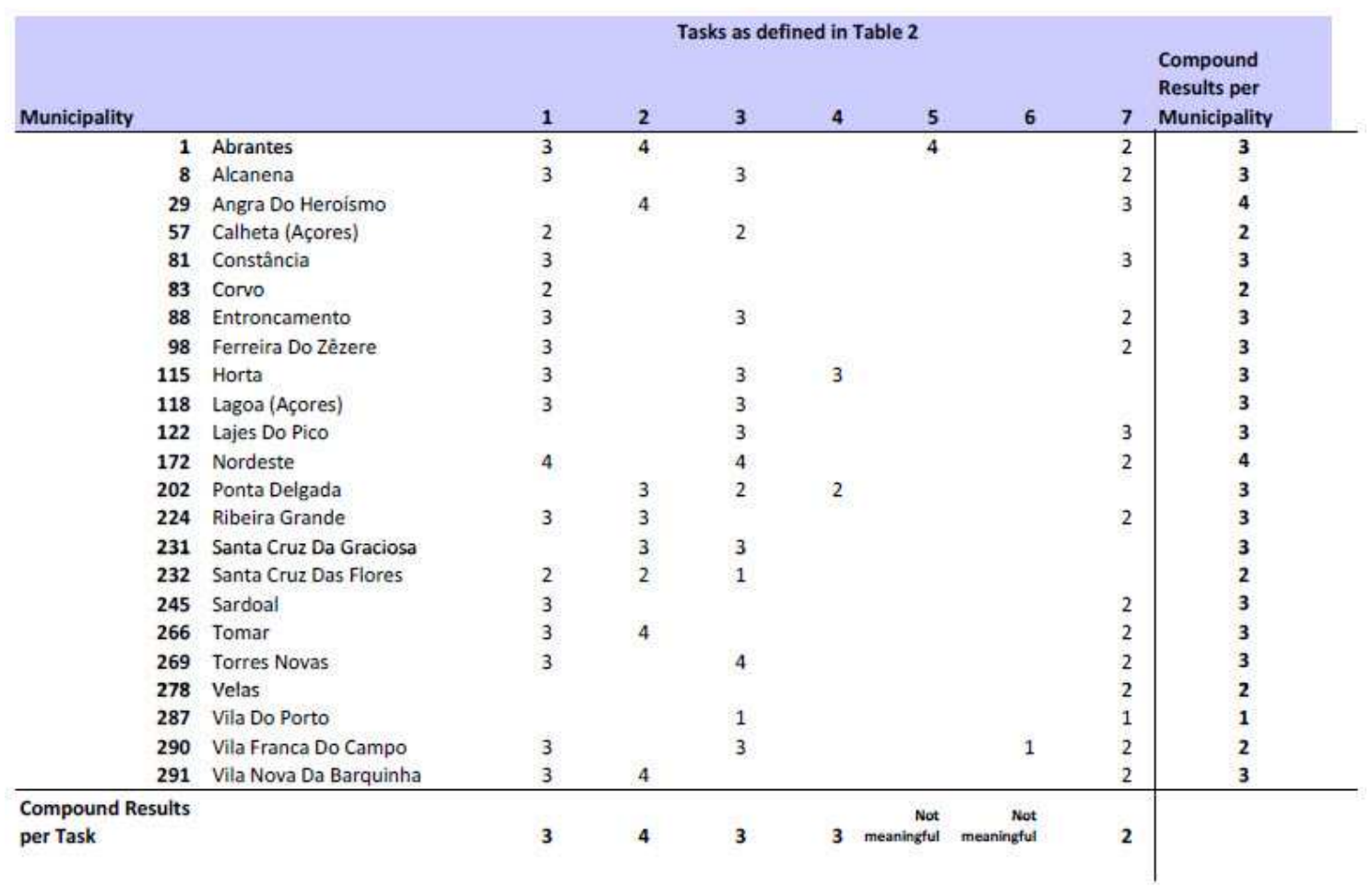

Table 3. Overall evaluation of task performance in terms of usability for digital inclusion.

In fact, the scenario found was one of average support for digital inclusion. This was evident not only from the individual municipal website scores but also from the overall compound data view, as shown in Figure 3. From this analysis it becomes apparent that only 9 per cent of the municipalities' websites scored 'good' whilst 22 per cent actually scored 'poor'. The vast majority (65 per cent) scored 'reasonable'.

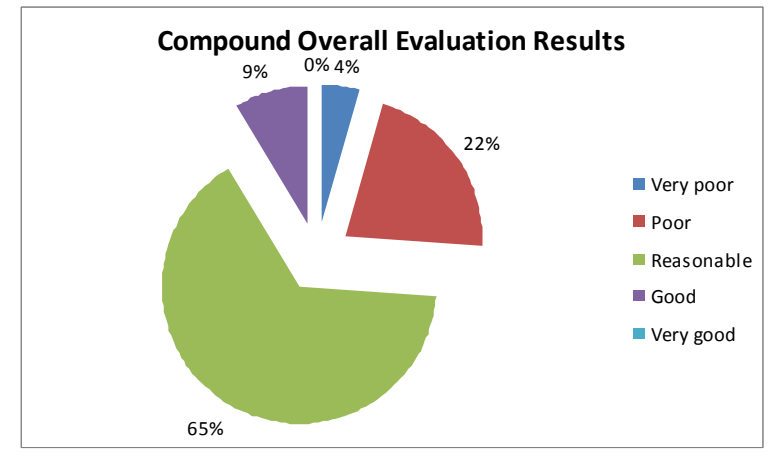

Figure 3. Compound results emerging from the frequency analysis of the results for each municipality. 
These results are far from being satisfactory, but require a closer analysis in order to understand where the failure was actually occurring and how these sites were failing to support digital inclusion. Table 3 was based on the qualifying comments that were collected to justify the score given during the $\mathrm{CW}$. These comments were stored during the $\mathrm{CW}$ in the MunAva system described earlier. Analysis of the results in Table 4 makes it clear that the majority of problems encountered were outside the traditional areas of concern in usability. In fact, those that are situated at the traditional centre of usability, namely navigation, multimedia objects and page layout, are the ones that fair better in the $\mathrm{CW}$ performed. The relative importance of these problems in the study is probably best represented by Figure 4.

\begin{tabular}{|c|c|c|c|c|c|c|c|c|c|c|c|}
\hline \multirow[b]{2}{*}{ Municipality } & \multicolumn{11}{|c|}{ Usability problems } \\
\hline & $\begin{array}{r}\text { Content } \\
\text { Organization }\end{array}$ & $\begin{array}{l}\text { Graphics, } \\
\text { Images and } \\
\text { Multimedia }\end{array}$ & $\begin{array}{l}\text { Headings, } \\
\text { Titles and } \\
\text { Labels }\end{array}$ & Links & Navigation & $\begin{array}{l}\text { Optimizing } \\
\text { the User } \\
\text { Experience }\end{array}$ & $\begin{array}{r}\text { Page } \\
\text { Layout }\end{array}$ & $\begin{array}{r}\text { Screen- } \\
\text { Based } \\
\text { Controls } \\
\text { (Widgets) }\end{array}$ & $\begin{array}{l}\text { Scrolling } \\
\text { and Paging }\end{array}$ & $\begin{array}{r}\text { Writing } \\
\text { Web } \\
\text { Content }\end{array}$ & Totals \\
\hline Abrantes & 15 & 1 & 2 & 21 & 6 & 19 & 4 & 13 & 17 & 5 & 103 \\
\hline Horta & 8 & 6 & 3 & 17 & 3 & 23 & 4 & 30 & 8 & 6 & 108 \\
\hline Lagoa (Açores) & 8 & 2 & 2 & 13 & 0 & 11 & 9 & 12 & 9 & 5 & 71 \\
\hline Lajes das Flores & 0 & 0 & 0 & 0 & 0 & 0 & 0 & 0 & 0 & 0 & 0 \\
\hline Lajes dos Pico & 1 & 3 & 1 & 13 & 0 & 7 & 6 & 13 & 4 & 4 & 52 \\
\hline Madalena & 0 & 0 & 0 & 0 & 0 & 0 & 0 & 0 & 0 & 0 & 0 \\
\hline Nordeste & 1 & 8 & 3 & 15 & 0 & 18 & 8 & 12 & 8 & 10 & 83 \\
\hline Ponta_Delgada & 8 & 3 & 4 & 17 & 3 & 12 & 5 & 9 & 15 & 6 & 82 \\
\hline Povoação & 0 & 0 & 0 & 0 & 0 & 0 & 0 & 0 & 0 & 0 & 0 \\
\hline Praia da Vitória & 0 & 0 & 0 & 0 & 0 & 0 & 0 & 0 & 0 & 0 & 0 \\
\hline Ribeira Grande & 7 & 3 & 7 & 15 & 2 & 12 & 3 & 13 & 14 & 5 & 81 \\
\hline Santa Cruz da Graciosa & 6 & 2 & 3 & 13 & 1 & 5 & 6 & 8 & 12 & 3 & 59 \\
\hline Santa Cruz das Flores & 14 & 5 & 9 & 24 & 1 & 22 & 10 & 20 & 7 & 6 & 118 \\
\hline São Roque do Pico & 0 & 0 & 0 & 0 & 0 & 0 & 0 & 0 & 0 & 0 & 0 \\
\hline Sardoal & 3 & 2 & 1 & 9 & 1 & 13 & 5 & 12 & 8 & 5 & 59 \\
\hline Tomar & 5 & 1 & 0 & 12 & 1 & 13 & 4 & 11 & 13 & 4 & 64 \\
\hline Torres Novas & 5 & 2 & 3 & 12 & 1 & 23 & 8 & 20 & 13 & 7 & 94 \\
\hline Velas & 2 & 1 & 2 & 0 & 0 & 3 & 0 & 4 & 1 & 2 & 15 \\
\hline Vila do Porto & 13 & 2 & 4 & 11 & 0 & 15 & 7 & 15 & 9 & 7 & 83 \\
\hline Angra do Heroísmo & 1 & 2 & 1 & 6 & 2 & 6 & 0 & 3 & 10 & 2 & 33 \\
\hline Vila Franca do Campo & 13 & 7 & 4 & 17 & 0 & 30 & 5 & 16 & 24 & 9 & 125 \\
\hline Vila Nova da Barquinha & 5 & 1 & 0 & 14 & 1 & 15 & 4 & 10 & 15 & 4 & 69 \\
\hline Calheta (Açores) & 8 & 3 & 5 & 14 & 1 & 17 & 8 & 20 & 4 & 8 & 88 \\
\hline Alcanena & 8 & 4 & 3 & 17 & 0 & 24 & 8 & 25 & 15 & 5 & 109 \\
\hline Constãncia & 5 & 4 & 1 & 10 & 1 & 10 & 4 & 9 & 7 & 4 & 55 \\
\hline Corvo & 5 & 2 & 1 & 4 & 0 & 10 & 4 & 9 & 7 & 2 & 44 \\
\hline Entroncamento & 9 & 2 & 2 & 17 & 1 & 21 & 8 & 20 & 12 & 4 & 96 \\
\hline Ferreira do Zêzere & 4 & 2 & 1 & 9 & 1 & 15 & 4 & 10 & 8 & 3 & 57 \\
\hline Totals & 154 & 68 & 62 & 300 & 26 & 344 & 124 & 314 & 240 & 116 & 1748 \\
\hline
\end{tabular}

Table 4. Usability Problems encountered during the Evaluation Performed

The majority of problems encountered are related to content organisation, screen-based controls, scrolling and paging, as well as clarity and identification of links. These problems are of crucial importance in terms of digital inclusion as they are bound to be the ones contributing more to user disorientation, poor exploitation of the services offered and eventually alienation from using the e-government websites. 


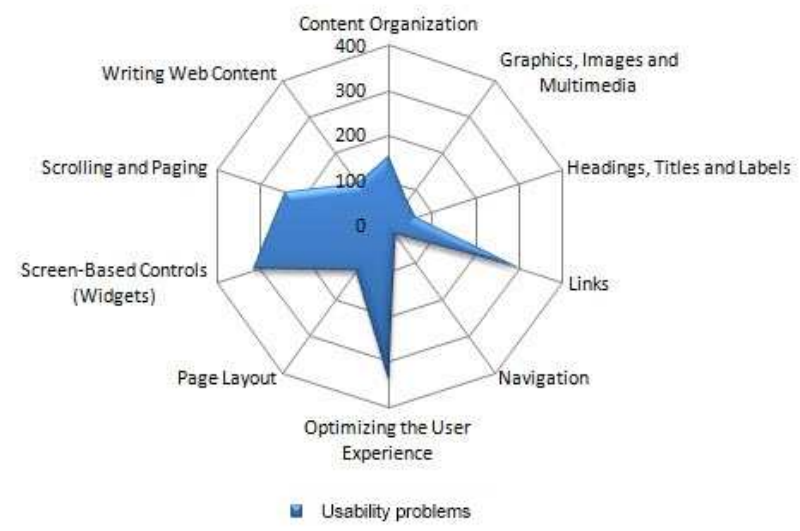

Figure 4. Visual Representation of Usability Problems encountered during the Evaluation Performed.

\section{Conclusions}

In general terms, the CW conducted was deemed a successful process, and was completed with satisfactory results. The overall findings showed that there was poor consideration of digital inclusion issues and guidelines in the design of local e-government sites in Portugal. The subset of 53 guidelines proposed was extremely useful in guiding the study, which otherwise would have shown a very different picture. The analysis of the websites used the traditional usability technique of applying a quantitative five-point Likert scale, which was complemented by a qualitative qualification and justification of the score given. This enabled a richer analysis of results and an identification of problems linked to digital literacies.

The study attempts to make two main theoretical contributions: on one side the linking of usability guidelines with digital literacies, and on the other an extension of traditional information literacy models by proposing an extension to SCONUL.

Finally, the study attempts to make a practical contribution to the current situation in Portugal. In truth, the main conclusion emerging from this study points to a rather average performance of municipal e-government sites in relation to digital inclusion. This average scenario is clearly apparent from the fact that only two of the municipalities' websites evaluated scored 'good' and a clear majority of them (65 per cent) scored 'reasonable'. On an encouraging note, it was clear that if central usability parameters had been used these sites would have scored rather better, justifying the findings of the study by Capgemini et al. (2010).

This less than good scenario is particularly worrying in a country with lower than average literacy skills, like Portugal, and indicates that there is still a need for an important effort on both awareness of digital literacies and the digital gap. There is also a need to understand much better the link between digital literacies and usability, so that these concepts can be embedded in web design for e-government. In fact, and since the information literacy problem in Portugal can only be resolved in the long term, the effort today needs to be focused on this type of inclusive web design. 


\section{References}

Bagchi, K. (2005). Factors Contributing to Global Digital Divide: Some Empirical Results. Journal of Global Information Technology Management, 8(3), 47 - 65.

Bainton, T. (2001). Information Literacy and Academic Libraries: The SCONUL Approach (UK/Ireland). Paper presented at the Proceedings of the 67th IFLA Council and General Conference, August 16-25, 2001, Boston, USA.

Bawden, D. (2001). Information and digital literacies: a review of concepts. Journal of Documentation, 57(2), 218-259.

Bélanger, F., \& Carter, L. (2008). Trust and risk in e-government adoption. The Journal of Strategic Information Systems, 17(2), 165-176.

Bindé, J. (2005). Towards Knowledge Societies: UNESCO world report., UNESCO reference works. Paris: United Nations Educational, Scientific and Cultural Organization.

Blackmon, M. H., Polson, P. G., Kitajima, M., \& Lewis, C. (2002). Cognitive walkthrough for the web. Paper presented at the Proceedings of the SIGCHI conference on Human factors in computing systems: Changing our world, changing ourselves.

Brajnik, G. (2004). Using automatic tools in accessibility and usability assurance processes. Paper presented at the 8th ERCIM Workshop" User Interfaces For All", June, Vienna.

Capgemini, IDC, Rand Europe, Sogeti, \& DTi. (2010). Digitizing Public Services in Europe: Putting ambition into action. 9th Benchmark Measurement. December 2010: European Commission. Directorate General Information Society and Media.

Carter, L., \& Bélanger, F. (2004). The Influence of Perceived Characteristics of Innovating on e-Government Adoption. Electronic Journal of e-Government (EJEG), 2(1), 11-20.

Castells, M. (2001). A Galáxia Internet - Reflexões sobre Internet, Negócios e Sociedade. Lisboa: Fundação Calouste Gulbenkian.

DiMaggio, P., Hargittai, E., Neuman, W. R., \& Robinson, J. P. (2001). Social Implications of the Internet. Annual Review of Sociology, 27, 307 - 336.

Dix, A., Finley, J., Abowd, G. D., \& Beale, R. (2004). Human-computer interaction (3rd ed.). Upper Saddle River, NJ, USA: Prentice-Hall, Inc.

Doyle, C. S. (1992). Outcome Measures for Information Literacy within the National Education Goals of 1990, Final Report to National Forum on Information Literacy, Summary of Findings. Syracuse, NY.

Dutton, W. H. (2004). Social Transformation in an Information Society: Rethinking Access to You and the World. Paris: UNESCO, United Nations Educational, Scientific and Cultural Organization. 
Educational Testing Service. (2002). Digital transformation: A framework for ICT literacy. A report of the international ICT literacy panel. Princeton, New Jersey.

eEurope Advisory Group. (2005). e-Inclusion: New challenges and policy recommendations: European Commission.

eInclusion@EU. (2004). Strengthening eInclusion and eAccessibility across Europe. Retrieved 16 de Maio de 2005, from http://www.einclusioneu.org/files/eInclusion_D1-1_analytic-framework_final.PDF

European Commission (2009). eGovernment in Portugal. Brussels: eGovernment Practice Editorial Team, European Dynamics SA.

Evans, D., \& Yen, D. C. (2006). E-Government: Evolving relationship of citizens and government, domestic, and international development. Government Information Quarterly, 23(2), 207-235.

Guillén, M. F., \& Suárez, S. L. (2005). Explaining the Global Digital Divide: Economic, Political, and Sociological Drivers of Cross-National Internet Use. Social Forces, 84(2), 681-708.

Hargittai, E. (2002). Second-Level Digital Divide: Differences in People's Online Skills. First Monday, 7(4).

Heeks, R. (2005). e-Government as a Carrier of Context. Journal of Public Policy, 25(01), 5174.

Heeks, R., \& Bailur, S. (2007). Analyzing e-government research: Perspectives, philosophies, theories, methods, and practice. Government Information Quarterly, 24(2), 243-265.

Hoffman, M., \& Blake, J. (2003). Computer literacy: today and tomorrow. Journal of Computing Sciences in Small Colleges, 18(5), 221-233.

Hofstetter, F. T. (2003). Advanced web design. Boston: McGraw-Hill.

Huang, H., Keser, C., Leland, J., \& Shachat, J. (2003). Trust, the Internet, and the digital divide. IBM Systems Journal, 42(3), 507-518.

Irani, Z., Elliman, T., \& Jackson, P. (2007). Electronic transformation of government in the UK: a research agenda. European Journal of Information Systems, 16(4), 327-335.

Kummer, M. (2003). Information society: Promise and risks. Organisation for Economic Cooperation and Development. The OECD Observer(240/241), 25 - 26.

Lemke, J. (2000). Multimedia literacy demands of the scientific curriculum. Linguistics and Education, 10(3), 247-271.

Lemke, J. L. (1998). Metamedia literacy: Transforming meanings and media (Handbook of literacy and technology: Transformations in a post-typographic world ed.): Mahwah, NJ: Erlbaum. 
Lenox, M. F., \& Walker, M. L. (1993). Information Literacy in the Educational Process. Educational Forum, 57(2), 312-324.

Lewis, C., \& Rieman, J. Task Centered User Interface Design: A Practical Introduction. University of Colorado, Boulder. This is shareware book that is available online at the following url: ftp://ftp. cs. colorado. edu/pub/cs/distribs/clewis/HCI-Design-Book.

Li, B. (2005). On the barriers to the development of e-government in China. Paper presented at the Proceedings of the 7th international conference on Electronic commerce.

Lynch, B. P. (2002). The Digital Divide or the Digital Connection: A U.S. Perspective. First Monday, 7(10).

Madden, M., Fox, S., Smith, A., \& Vitak, J. (2007). Digital Footprints: Online identity management and search in the age of transparency: Pew Internet \& American Life Project.

Millard, J. (2004). eUSER D1.1: Conceptual and Analytical Framework. Evidence-based support for the design and delivery of usercentred online public services. First Version.

Nielsen, J. (1993). Usability Engineering. London: Morgan Kaufmann.

Nielsen, J., \& Loranger, H. (2006). Prioritizing Web Usability. Berkeley, California: New Riders, Pearson Education.

Norris, P. (2001a). The Digital Divide Digital Divide: Civic Engagement, Information Poverty, and the Internet Worldwide: Cambridge University Press.

Norris, P. (2001b). Digital divide: Civic engagement, information poverty, and the Internet worldwide: Cambridge University Press.

OECD. (2001). Understanding the Digital Divide. Paris.

Polson, P. G., Lewis, C., Rieman, J., \& Wharton, C. (1992). Cognitive walkthroughs: a method for theory-based evaluation of user interfaces. International Journal of manmachine studies, 36(5), 741-773.

Portuguese Ministry of Science, Technology and Higher Education (2005). Connecting Portugal - A program of action in the Portuguese Government Technological Plan: Mobilizing the Information and Knowledge Society. Lisbon: Prime Minister's Office. Retrieved 22-08-2011, from http://www.english.umic.pt/images/stories/publicacoes2/ conn_pt.pdf

Prensky, M. (2001). Digital natives, digital immigrants Part 1. On the horizon, 9(5), 1-6.

Rieman, J., Franzke, M., \& Redmiles, D. (1995). Usability evaluation with the cognitive walkthrough. Paper presented at the Conference companion on Human factors in computing systems, CHI '95, New York, NY, USA. 
Rohn, J. A., Spool, J., Ektare, M., Koyani, S., Muller, M., \& Redish, J. G. (2002). Usability in practice: alternatives to formative evaluations-evolution and revolution. Paper presented at the Conference on Human Factors in Computing Systems, Minneapolis, Minnesota, USA.

SCONUL. (2004). Learning Outcomes and Information Literacy. London, UK: The Society of College, National and University Librarians.

Shetzer, H., \& Warschauer, M. (2000). An Electronic Literacy Approach to Network-Based Language Teaching In M. Warschauer \& R. Kern (Ed.), Network-based Language Teaching: Concepts and practice (pp. 171 - 185). New York: Cambridge University Press.

Smith, S. L., \& Mosier, J. N. (1986). Guidelines for Designing User Interface Software. Retrieved 10-05-2007, from http://hcibib.org/sam/index.html

Souza, F., \& Bevan, N. (1990). The use of guidelines in menu interface design: Evaluation of a draft standard. Paper presented at the Proceedings of IFIP INTERACT'90: HumanComputer Interaction, Cambridge, UK.

Tonkin, E. (2005). Making the case for a wiki. Ariadne, 42. Retrieved from http://www.ariadne.ac.uk/issue42/tonkin/

Traunmuller, R., \& Wimmer, M. (2001). Directions in e-government: processes, portals, knowledge. Paper presented at the Proceedings. 12th International Workshop on Database and Expert Systems Applications, Munich, Germany.

U.S. Health and Human Services Department. (2006). Research-based Web Design \& Usability Guidelines Available from http://usability.gov/guidelines/index.html

Underwood, J. D. M. (2007). Rethinking the Digital Divide: impacts on student tutor relationships. European Journal of Education, 42(2), 213-222.

Wareing, S. (2004). What's a learning outcome? Learning Outcomes and Information Literacy. London, UK: The Society of College National and University Librarians (SCONUL).

Warschauer, M. (2002). Reconceptualizing the Digital Divide. First Monday, 7(7).

Warschauer, M. (2003). Technology and Social Inclusion: Rethinking the Digital Divide. Cambridge, Massachusetts: MIT Press.

Warschauer, M. (2004). Of Digital Divides and Social Multipliers: Combining Language and Technology for Human Development. Moscow: UNESCO Institute for Information Technologies in Education.

Warschauer, M. (2007). Technology and writing. In C. Davison \& J. Cummins (Eds.), International Handbook of English Language Teaching (pp. 907-917). Norwell, MA: Springer. 
Waycott, J., Bennett, S., Kennedy, G., Dalgarno, B., \& Gray, K. (2010). Digital divides? Student and staff perceptions of information and communication technologies. Computers \& Education, 54(4), 1202-1211.

Webber, S., \& Johnston, B. (2000). Conceptions of information literacy: new perspectives and implications. Journal of Information Science, 26(6), 381.

Wharton, C., Bradford, J., Jeffries, R., \& Franzke, M. (1992). Applying cognitive walkthroughs to more complex user interfaces: experiences, issues, and recommendations. Paper presented at the Proceedings of the SIGCHI conference on Human factors in computing systems, Monterey, California, United States.

Wharton, C., Rieman, J., Lewis, C., \& Polson, P. (1994). The Cognitive Walkthrough Method: A Practitioner's Guide. In J. Nielsen \& R. L. Mack (Eds.), Usability Inspections Methods (pp. 105 - 140). New York: John Wiley.

Williams, K. (2003). Literacy and Computer Literacy: Analyzing the NRC's "Being Fluent with Information Technology". Journal of Literacy and Technology, 3(1), 1-20.

World Bank. (2005). A Definition of $E^{*}$ Government. Retrieved 20-11-2005, from http://www1.worldbank.org/publicsector/egov/definition.htm

Zorrinho, C. (2006). Technological Plan A growth strategy based on Knowledge, Technology and Innovation Presidency of the Council of Ministers: Cabinet of the National Coordinator of the Technological Plan and the Lisbon Strategy. Retrieved 22-082011, from http://www.planotecnologico.pt/document/technological_plan_ presentation_document.pdf. 
Annex 1 - Portuguese Indicators for the development of the Information Society (adapted from Portuguese Ministry of Science, Technology and Higher Education (2005)).

\begin{tabular}{|c|c|c|c|c|c|}
\hline \multirow{2}{*}{ Indicators } & \multirow{2}{*}{$\begin{array}{c}\begin{array}{c}\text { Proposed } \\
\text { target }\end{array} \\
2010\end{array}$} & \multicolumn{4}{|c|}{ P.M.: Indicator on the base year } \\
\hline & & \multicolumn{2}{|c|}{ Indicator } & Year & Notes \\
\hline $\begin{array}{l}\text { Qualification and Knowledge } \\
\text { (Qualifying the Portuguese people } \\
\text { for the knowledge society) }\end{array}$ & & Portugal & $\begin{array}{l}\text { European } \\
\text { Union (25) }\end{array}$ & & \\
\hline $\begin{array}{l}\text { 1. Population having a higher } \\
\text { education degree (\% of the age }\end{array}$ & $--15 \%$ & $11,0 \%$ & $22,5 \%$ & 2003 & \\
\hline $\begin{array}{l}\text { 2. Population having a secondary } \\
\text { education degree (\% of the age } \\
\text { group } 20-24 \text { years) }\end{array}$ & $65 \%$ & $49,0 \%$ & $76,7 \%$ & 2004 & \\
\hline $\begin{array}{l}\text { 3. Population having a diploma in } \\
\text { science and technology per } 1000 \\
\text { inhabitants (between } 20-29 \text { years) }\end{array}$ & 12 & 8,2 & 12,5 & 2003 & \\
\hline 4. Researchers per 1000 employees & $\begin{array}{r}5,3 \\
50 \%\end{array}$ & $\begin{array}{r}3,5 \\
100\end{array}$ & 5,3 & 2001 & \\
\hline $\begin{array}{l}\text { 5. Percentage of households having } \\
\text { a broadband Internet connection }\end{array}$ & $50 \%$ & $12 \%$ & 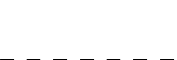 & 2004 & \\
\hline 6. Lifelong Training & $-\overline{12,5 \%}$ & $\overline{4,8 \%}$ & $\overline{9,4 \%} \overline{-}$ & $20 \overline{0}$ & \\
\hline $\begin{array}{l}\text { Science and Technology (to } \\
\text { overcome the scientific and } \\
\text { technological backwardness) }\end{array}$ & & & & & \\
\hline $\begin{array}{l}\text { 7. Population having a recent PhD in } \\
\text { S\&T per } 1000 \text { inhabitants (between } \\
25-34 \text { years) }\end{array}$ & $0,4 \overline{5}$ & 0,3 & 0,49 & 2003 & \\
\hline $\begin{array}{l}\text { 8. Scientific production per million } \\
\text { inhabitants }\end{array}$ & 609 & 406 & 639 & 2003 & \\
\hline $\begin{array}{l}\text { 9. Total Personnel (ETI) in R\&D per } \\
\text { mill of working population }\end{array}$ & 7,5 & 4,3 & 9,4 & 2001 & $\stackrel{*}{*}$ \\
\hline 10. Researchers (ETI) per mill of & 6,0 & 3,6 & 5,4 & 2004 & UF 15 \\
\hline $\begin{array}{l}\text { 11. Public expenditure in } \mathrm{R} \& \mathrm{D} \text { as } \% \\
\text { of GDP }\end{array}$ & $1,0 \%$ & $0,6 \%$ & $0,7 \%$ & 2002 & \\
\hline $\begin{array}{l}\text { 12. Company expenditure in R\&D as } \\
\% \text { of GDP }\end{array}$ & 0,8 & $0,3 \%$ & $1,3 \%$ & 2002 & \\
\hline $\begin{array}{l}\text { Competitiveness } \text { and Innovation } \\
\text { (Giving a new momentum to } \\
\text { innovation) }\end{array}$ & & & & & \\
\hline $\begin{array}{l}13 . \text { mployment in medium and } \\
\text { high-tech industries as \% of total } \\
\text { employment }\end{array}$ & $\overline{4, \overline{7}}$ & $3,1 \%$ & $6,6 \%$ & 2003 & \\
\hline $\begin{array}{l}\text { 14. Employment in high-tech } \\
\text { services as \% of total employment }\end{array}$ & $1,8 \%$ & $1,4 \%$ & $3,2 \%$ & 2003 & \\
\hline $\begin{array}{l}\text { 15. Added value of medium and } \\
\text { hiah-tech sectors in industry }\end{array}$ & $6,2 \%$ & $4,9 \%$ & $15,8 \% *$ & 2002 & $\stackrel{*}{*}$ \\
\hline $\begin{array}{l}\text { 16. Added value of high-tech } \\
\text { services }\end{array}$ & $6,0 \%$ & $4,0 \%$ & $6,4 \% *$ & 2002 & UE15 \\
\hline 17. Exports of high-tech products as & $11,4 \%$ & $7,4 \%$ & $17,8 \%$ & 2003 & \\
\hline $\begin{array}{l}\text { medium and high-tech sectors as \% } \\
\text { of total enterprises created within the } \\
\text { same period }\end{array}$ & $12,5 \%$ & & & & \\
\hline $\begin{array}{l}\text { 19. EPO Patents per million } \\
\text { inhabitants }\end{array}$ & 12 & 4,3 & 133,6 & 2002 & $\stackrel{*}{*}$ \\
\hline $\begin{array}{l}\text { 20. Community trademarks } \\
\text { registered per million inhabitants }\end{array}$ & 50 & 21 & $59^{*}$ & 2004 & UE15 \\
\hline $\begin{array}{l}\% \text { of GDP } \\
\% \text {. In venture capital as }\end{array}$ & $0,15 \%$ & $0,12 \%$ & $0,11 \% *$ & 2004 & UE15 \\
\hline
\end{tabular}




\section{Annex 2 - Usability Guidelines for Digital Inclusion}

\begin{tabular}{|c|c|c|}
\hline $2: 9$ & $\begin{array}{l}\text { Format Information for Reading } \\
\text { and Printing }\end{array}$ & Prepare information with the expectation that it will be either read online or printed \\
\hline $2: 16$ & Provide Assistance to Users & Provide assistance for users who need additional help with the website \\
\hline $2: \mathrm{a}$ & Provide Feedback to Users & Provide users with appropriate feedback about what is going on \\
\hline $5: 2$ & $\begin{array}{l}\text { Show All Major Options on the } \\
\text { Homepage }\end{array}$ & $\begin{array}{l}\text { Present all major options on the } \\
\text { homepage }\end{array}$ \\
\hline $5: 5$ & Limit Prose Text on the Homepage & Limit the amount of prose text on the homepage \\
\hline $6: 1$ & Avoid Cluttered Displays & Create pages that are not considered cluttered by users \\
\hline $6: 3$ & $\begin{array}{l}\text { Place Important Items at Top } \\
\text { Centre }\end{array}$ & $\begin{array}{l}\text { Put the most important items at the top centre of the Web page to facilitate users' finding of the } \\
\text { information }\end{array}$ \\
\hline $6: 4$ & Structure for Easy Comparison & $\begin{array}{l}\text { Structure pages so that items can be easily compared when users must analyse those items to } \\
\text { discern similarities, differences, trends, and relationships }\end{array}$ \\
\hline $6: 6$ & Optimize Display Density & $\begin{array}{l}\text { To facilitate the finding of target information on a page, create pages that are not too crowded } \\
\text { with items of information }\end{array}$ \\
\hline $6: 7$ & Align Items on a Page & Visually align page elements, either vertically or horizontally \\
\hline $7: 1$ & Provide Navigational Options & Do not create or direct users into pages that have no navigational options \\
\hline $7: 2$ & $\begin{array}{l}\text { Differentiate and Group } \\
\text { Navigation Elements }\end{array}$ & $\begin{array}{l}\text { Clearly differentiate navigation elements from one another, but group and place them in a } \\
\text { consistent and easy-to-find place on each page }\end{array}$ \\
\hline $7: 8$ & Keep Navigation-Only Pages Short & Do not require users to scroll purely navigational pages \\
\hline $7: 10$ & Use Site Maps & Use site maps for websites that have many pages \\
\hline $8: 1$ & Use Scrolling Pages For Reading & Use an appropriate page layout to eliminate the need for users to scroll horizontally \\
\hline $8: 2$ & $\begin{array}{l}\text { Facilitate Rapid Scrolling While } \\
\text { Reading }\end{array}$ & Facilitate fast scrolling by highlighting major items \\
\hline $8: 4$ & Use Paging Rather Than Scrolling & If users' system response times are reasonably fast, use paging rather than scrolling \\
\hline $9: 1$ & Use Clear Category Labels & $\begin{array}{l}\text { Ensure that category labels, including links, clearly reflect the information and items contained } \\
\text { within the category }\end{array}$ \\
\hline $9: 3$ & Use Descriptive Headings Liberally & Use descriptive headings liberally throughout a website \\
\hline $9: 5$ & Highlight Critical Data & $\begin{array}{l}\text { Visually distinguish (i.e. highlight) important page items that require user attention, particularly } \\
\text { when those items are displayed infrequently. }\end{array}$ \\
\hline $9: 8$ & $\begin{array}{l}\text { Provide Users with Good Ways to } \\
\text { Reduce Options }\end{array}$ & Provide users with good ways to reduce their available options as efficiently as possible \\
\hline $10: 1$ & Use Meaningful Link Labels & $\begin{array}{l}\text { Use link labels and concepts that are meaningful, understandable, and easily differentiated by } \\
\text { users rather than designers }\end{array}$ \\
\hline $10: 3$ & $\begin{array}{l}\text { Match Link Names with Their } \\
\text { Destination Pages }\end{array}$ & Make the link text consistent with the title or headings on the destination (i.e. target) page \\
\hline $10: 4$ & Avoid Misleading Cues to Click & $\begin{array}{l}\text { Ensure that items that are not clickable do not have characteristics that suggest that they are } \\
\text { clickable }\end{array}$ \\
\hline 10:6 & Use Text for Links & Use text links rather than image links \\
\hline $10: 7$ & Designate Used Links & Use colour changes to indicate to users when a link has been visited \\
\hline $10: 8$ & $\begin{array}{l}\text { Provide Consistent Clickability } \\
\text { Cues }\end{array}$ & Provide sufficient cues to indicate clearly to users that an item is clickable \\
\hline 11:6 & $\begin{array}{l}\text { Use Attention-Attracting Features } \\
\text { when Appropriate }\end{array}$ & Use attention-attracting features with caution and only when they are highly relevant \\
\hline $13: 1$ & $\begin{array}{l}\text { Distinguish Required and Optional } \\
\text { Data Entry Fields }\end{array}$ & Distinguish clearly and consistently between required and optional data entry fields. \\
\hline $13: 2$ & Label Pushbuttons Clearly & Ensure that a pushbutton's label clearly indicates its action \\
\hline $13: 5$ & Label Data Entry Fields Clearly & $\begin{array}{l}\text { Display an associated label for each data entry field to help users understand what entries are } \\
\text { desired }\end{array}$ \\
\hline
\end{tabular}




\begin{tabular}{|c|c|c|}
\hline $13: 10$ & Use Familiar Widgets & Use widgets that are familiar to your users and employ them in their commonly used manner \\
\hline 13:11 & Anticipate Typical User Errors & Use the computer to detect errors made by users \\
\hline $14: 2$ & Label Clickable Images & Ensure that all clickable images are either labelled or readily understood by typical users \\
\hline $14: 5$ & Include Logos & Place your organisation's logo in a consistent place on every page \\
\hline $14: 6$ & $\begin{array}{l}\text { Graphics Should Not Look like } \\
\text { Banner Ads }\end{array}$ & Do not make important images look like banner advertisements or gratuitous decorations \\
\hline $14: 8$ & $\begin{array}{l}\text { Ensure WebSite Images Convey } \\
\text { Intended Messages }\end{array}$ & Ensure that website images convey the intended message to users, not just to designers \\
\hline $14: 15$ & Use Images to Facilitate Learning & To facilitate learning, use images rather than text whenever possible \\
\hline $15: 1$ & Make Action Sequences Clear & $\begin{array}{l}\text { When describing an action or task that has a natural order or sequence (assembly instructions, } \\
\text { troubleshooting, etc.), structure the content so that the sequence is obvious and consistent }\end{array}$ \\
\hline $15: 2$ & Avoid Jargon & Do not use words that typical users may not understand \\
\hline $15: 4$ & $\begin{array}{l}\text { Define Acronyms and } \\
\text { Abbreviations }\end{array}$ & Do not use unfamiliar or undefined acronyms or abbreviations on websites \\
\hline $15: 6$ & Use Mixed Case with Prose & Display continuous (prose) text using mixed upper and lower case letters \\
\hline $15: 7$ & $\begin{array}{l}\text { Limit the Number of Words and } \\
\text { Sentences }\end{array}$ & $\begin{array}{l}\text { To optimize reading comprehension, minimize the number of words in sentences, and the number } \\
\text { of sentences in paragraphs }\end{array}$ \\
\hline $16: 1$ & Organise Information Clearly & $\begin{array}{l}\text { Organise information at each level of the website so that it shows a clear and logical structure to } \\
\text { typical users }\end{array}$ \\
\hline $16: 2$ & Facilitate Scanning & $\begin{array}{l}\text { Structure each content page to facilitate scanning: use clear, well-located headings; short phrases } \\
\text { and sentences; and small readable paragraphs }\end{array}$ \\
\hline $16: 3$ & $\begin{array}{l}\text { Ensure that Necessary Information } \\
\text { is Displayed }\end{array}$ & $\begin{array}{l}\text { Ensure that all needed information is available and displayed on the page where and when it is } \\
\text { needed }\end{array}$ \\
\hline $16: 4$ & Group Related Elements & Group all related information and functions in order to decrease time spent searching or scanning \\
\hline $16: 6$ & $\begin{array}{l}\text { Design Quantitative Content for } \\
\text { Quick Understanding }\end{array}$ & Design quantitative information to reduce the time required to understand it \\
\hline $17: 1$ & Ensure Usable Search Results & $\begin{array}{l}\text { Ensure that the results of user searches provide the precise information being sought, and in a } \\
\text { format that matches users' expectations }\end{array}$ \\
\hline $17: 3$ & $\begin{array}{l}\text { Make Upper and Lower Case } \\
\text { Search Terms Equivalent }\end{array}$ & Treat user-entered upper and lower case letters as equivalent when entered as search terms \\
\hline $17: 5$ & $\begin{array}{l}\text { Design Search Around Users' } \\
\text { Terms }\end{array}$ & Construct a website's search engine to respond to users' terminology \\
\hline $17: 6$ & Allow Simple Searches & Structure the search engine to accommodate users who enter a small number of words \\
\hline $17: 9$ & Provide Search Templates & Provide templates to facilitate the use of search engines \\
\hline
\end{tabular}




\section{Annex 3 - Competences of information and knowledge society and usability guidelines for digital inclusion}

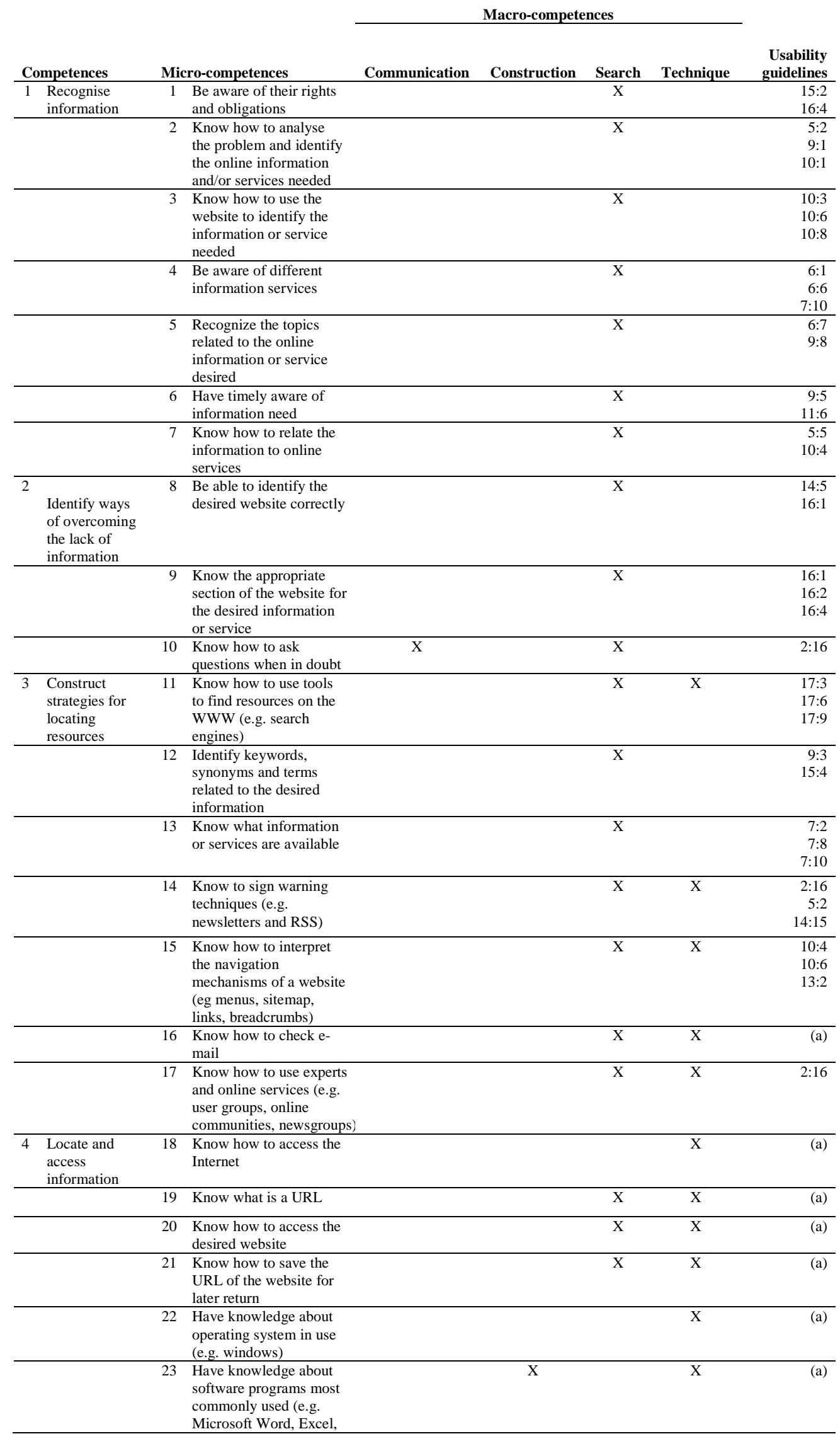


Macro-competences

\begin{tabular}{|c|c|c|c|c|c|c|c|}
\hline Competences & \multicolumn{2}{|c|}{ Micro-competences } & Communication & Construction & Search & Technique & $\begin{array}{r}\text { Usability } \\
\text { guidelines }\end{array}$ \\
\hline & & $\begin{array}{l}\text { Access, PowerPoint; } \\
\text { Adobe Acrobat Reader; } \\
\text { reproduction of sound } \\
\text { and image, e.g. } \\
\text { Windows Media Player) }\end{array}$ & & & & & \\
\hline & 24 & Know how to download & & & $\mathrm{X}$ & $\mathrm{X}$ & $14: 2$ \\
\hline & & & & & & & $14: 8$ \\
\hline & & & & & & & $14: 15$ \\
\hline & 25 & Know how to send & & & $\mathrm{X}$ & $\mathrm{X}$ & $14: 2$ \\
\hline & & information by e-mail & & & & & $14: 8$ \\
\hline & & & & & & & $14: 15$ \\
\hline & 26 & $\begin{array}{l}\text { Know how to use a Web } \\
\text { browser }\end{array}$ & & & $\mathrm{X}$ & $\mathrm{X}$ & (a) \\
\hline & 27 & Be aware of different & & & $\mathrm{X}$ & $\mathrm{X}$ & $2: 16$ \\
\hline & & $\begin{array}{l}\text { types of files (e.g. pdf, } \\
\text { doc, xls, xml) }\end{array}$ & & & & & \\
\hline & 28 & Know how to navigate & & & $\mathrm{X}$ & $\mathrm{X}$ & $8: 1$ \\
\hline & & the website (e.g. using & & & & & $10: 7$ \\
\hline & & menus, sitemap, links, & & & & & $14: 6$ \\
\hline & & breadcrumbs, tabs, & & & & & \\
\hline & & browser's back button, & & & & & \\
\hline & & scrollbar, links) & & & & & \\
\hline & 29 & Know how to seek & & & $\mathrm{X}$ & & $6: 3$ \\
\hline & & information or service & & & & & $16: 2$ \\
\hline & & & & & & & $16: 4$ \\
\hline & 30 & Know how to search & & & $\mathrm{X}$ & $\mathrm{X}$ & $17: 3$ \\
\hline & & (e.g. Boolean search, & & & & & $17: 5$ \\
\hline & & truncate) & & & & & $17: 6$ \\
\hline & 31 & Know how to use search & & & $\mathrm{X}$ & $\mathrm{X}$ & $17: 1$ \\
\hline & & engines & & & & & $17: 9$ \\
\hline & 32 & Know how to register on & $\mathrm{X}$ & $\mathrm{X}$ & $\mathrm{X}$ & $\mathrm{X}$ & $5: 2$ \\
\hline & & the website (username & & & & & $13: 1$ \\
\hline & & and password to access & & & & & $13: 5$ \\
\hline & & reserved area) & & & & & \\
\hline & 33 & Know how to & & & $\mathrm{X}$ & $\mathrm{X}$ & $5: 2$ \\
\hline & & authenticate to the & & & & & $13: 2$ \\
\hline & & website to access the & & & & & $13: 5$ \\
\hline & & private area & & & & & \\
\hline & 34 & Know how to adjust a & & & $\mathrm{X}$ & $\mathrm{X}$ & $2: 16$ \\
\hline & & $\begin{array}{l}\text { Web page (e.g. change } \\
\text { the font size) }\end{array}$ & & & & & \\
\hline Compare and & 35 & Know how to interpret & $\mathrm{X}$ & & $\mathrm{X}$ & & $15: 2$ \\
\hline evaluate & & the information found & & & & & $15: 6$ \\
\hline & 36 & Be able to assess & $\mathrm{X}$ & & $\mathrm{X}$ & & $15: 7$ \\
\hline & & critically what has been & & & & & $16: 3$ \\
\hline & & found according to the & & & & & $16: 6$ \\
\hline & & $\begin{array}{l}\text { quantity, quality and } \\
\text { relevance }\end{array}$ & & & & & \\
\hline & 37 & Know how to & $\mathrm{X}$ & & $\mathrm{X}$ & & $6: 4$ \\
\hline & & summarize, compare and & & & & & $6: 7$ \\
\hline & & integrate information to & & & & & $15: 7$ \\
\hline & & generate knowledge & & & & & \\
\hline 6 Organise and & 38 & Know how to do & & & $\mathrm{X}$ & $\mathrm{X}$ & $8: 1$ \\
\hline consult & & scrolling on a website & & & & & $8: 2$ \\
\hline & & page & & & & & $8: 4$ \\
\hline & 39 & Know how to go back to & & $\mathrm{X}$ & $\mathrm{X}$ & $\mathrm{X}$ & $7: 1$ \\
\hline & & previous page & & & & & \\
\hline & 40 & Know back if the form & & $X$ & & $\mathrm{X}$ & $7: 1$ \\
\hline & & has more than one page & & & & & $13: 2$ \\
\hline & 41 & Know how to save & & $\mathrm{X}$ & & $\mathrm{X}$ & $13: 2$ \\
\hline & & introduced data & & & & & \\
\hline & 42 & Know how to obtain the & & $\mathrm{X}$ & & & $2: 9$ \\
\hline & & proof of the task & & & & & $13: 2$ \\
\hline & & performed, if applicable & & & & & \\
\hline & & (e.g. print, e-mail, save & & & & & \\
\hline & & to the computer) & & & & & \\
\hline $7 \quad$ Synthesize and & 43 & Know how to create & & $\mathrm{X}$ & & $\mathrm{X}$ & (a) \\
\hline create & & $\begin{array}{l}\text { multimedia files (e.g. } \\
\text { pdf) }\end{array}$ & & & & & \\
\hline & 44 & Know how to fill out & & $\mathrm{X}$ & & $\mathrm{X}$ & $13: 1$ \\
\hline & & forms and surveys online & & & & & $13: 10$ \\
\hline & & & & & & & 13:11 \\
\hline & 45 & Know that tasks are & & $\mathrm{X}$ & & $\mathrm{X}$ & $2: 16$ \\
\hline & & being performed with & & & & & $2: \mathrm{a}$ \\
\hline & & $\begin{array}{l}\text { safety when security is } \\
\text { needed }\end{array}$ & & & & & \\
\hline
\end{tabular}


Macro-competences

\begin{tabular}{|c|c|c|c|c|c|c|c|}
\hline Competences & \multicolumn{2}{|c|}{ Micro-competences } & \multirow{2}{*}{$\frac{\text { Communication }}{\mathrm{X}}$} & \multirow{2}{*}{$\frac{\text { Construction }}{\mathrm{X}}$} & \multirow[t]{2}{*}{ Search } & \multirow[t]{2}{*}{ Technique } & \multirow{2}{*}{$\begin{array}{r}\begin{array}{r}\text { Usability } \\
\text { guidelines }\end{array} \\
15: 1 \\
2: \mathrm{a}\end{array}$} \\
\hline & 46 & $\begin{array}{l}\text { Know that the steps } \\
\text { necessary to complete } \\
\text { the task have not been } \\
\text { completed }\end{array}$ & & & & & \\
\hline & 47 & $\begin{array}{l}\text { Know that the task has } \\
\text { been completed } \\
\text { successfully }\end{array}$ & $\mathrm{X}$ & $\mathrm{X}$ & $\mathrm{X}$ & & $2: a$ \\
\hline & 48 & $\begin{array}{l}\text { Interpret the information } \\
\text { requested on the form }\end{array}$ & $\mathrm{X}$ & $\mathrm{X}$ & $\mathrm{X}$ & & $\begin{array}{l}13: 1 \\
13: 5\end{array}$ \\
\hline & 49 & Know how to upload & $\mathrm{X}$ & $\mathrm{X}$ & $\mathrm{X}$ & $\mathrm{X}$ & $\begin{array}{r}2: 16 \\
2: \mathrm{a}\end{array}$ \\
\hline \multirow[t]{12}{*}{$\begin{array}{ll}8 & \begin{array}{l}\text { Communicate } \\
(\mathrm{CMC})\end{array} \\
\end{array}$} & 50 & Know how to use e-mail & $\mathrm{X}$ & $\mathrm{X}$ & $\mathrm{X}$ & $\mathrm{X}$ & $2: 16$ \\
\hline & 51 & $\begin{array}{l}\text { Know how to use a } \\
\text { chatroom }\end{array}$ & $\mathrm{X}$ & & & $\mathrm{X}$ & $2: 16$ \\
\hline & 52 & $\begin{array}{l}\text { Know how to use online } \\
\text { conferencing }\end{array}$ & $\mathrm{X}$ & & & $\mathrm{X}$ & $2: 16$ \\
\hline & 53 & $\begin{array}{l}\text { Know how to use } \\
\text { discussion groups }\end{array}$ & $\mathrm{X}$ & & & $\mathrm{X}$ & $2: 16$ \\
\hline & 54 & $\begin{array}{l}\text { Know how to } \\
\text { communicate }\end{array}$ & $\mathrm{X}$ & $\mathrm{X}$ & $\mathrm{X}$ & & (a) \\
\hline & 55 & $\begin{array}{l}\text { Know how to write } \\
\text { clearly (plain text) }\end{array}$ & $\mathrm{X}$ & $\mathrm{X}$ & $\mathrm{X}$ & & (a) \\
\hline & 56 & $\begin{array}{l}\text { Know how to formulate } \\
\text { ideas }\end{array}$ & $X$ & $X$ & $\mathrm{X}$ & & (a) \\
\hline & 57 & Know how to summarize & $\mathrm{X}$ & $\mathrm{X}$ & $\mathrm{X}$ & & (a) \\
\hline & 58 & $\begin{array}{l}\text { Be aware of the formal } \\
\text { and informal rules of } \\
\text { writing online } \\
\text { (netiquette) }\end{array}$ & $\mathrm{X}$ & $\mathrm{X}$ & & & $2: 16$ \\
\hline & 59 & $\begin{array}{l}\text { Have capacity } \\
\text { forargumentation }\end{array}$ & $\mathrm{X}$ & & & & (a) \\
\hline & 60 & $\begin{array}{l}\text { Have capacity for } \\
\text { persuasion }\end{array}$ & $\mathrm{X}$ & & & & (a) \\
\hline & 61 & $\begin{array}{l}\text { Know how to } \\
\text { communicate in virtual } \\
\text { communities }\end{array}$ & $\mathrm{X}$ & & $\mathrm{X}$ & $\mathrm{X}$ & (a) \\
\hline
\end{tabular}

(a) Refers to an important competence that, although necessary for the successful use of e-government, cannot be supported directly by web design. Consequently, these competences were not used in the study. 